Potravinarstvo Slovak Journal of Food Sciences vol. 14, 2020, p. 1047-1054

https://doi.org/10.5219/1437

Received: 18 July 2020. Accepted: 30 October 2020. Available online: 28 November 2020 at www.potravinarstvo.com (C) 2020 Potravinarstvo Slovak Journal of Food Sciences, License: CC BY 3.0

ISSN 1337-0960 (online)

\title{
ENGINEERING MANAGEMENT OF STARTER CULTURES IN STUDY OF TEMPERATURE OF FERMENTATION OF SOUR-MILK DRINK WITH APIPRODUCTS
}

\author{
Ivan Rogoskii, Mikhailo Mushtruk, Liudmyla Titova, Olga Snezhko, Svitlana Rogach, \\ Oleh Blesnyuk, Yuriy Rosamaha, Tetiana Zubok, Oleksandr Yeremenko, Oleksandr Nadtochiy
}

\begin{abstract}
The article considers the solution of problematic issues of engineering management of poly fermentation in the study of fermentation temperature of sour-milk drink with apiproducts. In the development of fermented dairy products, the components that are part of them, changes in their composition, and properties in the interconnection are considered as a technological system. The authors took into account that food technologies based on the use of the pure culture of one microorganism are limited by the capabilities of its fermentation system systems, the ultimate goal may not be achieved even by changing the conditions and parameters of cultivation. To successfully carry out fermentation processes in the technological system, a combination of cultures, associations of microorganisms with a wide range of fermentation products in contrast to one culture is promising to use. All experimental samples on a set of indicators prevailed control ones. The leader was a sample fermented with yeast with an equal ratio of cultures at a temperature of $38-40{ }^{\circ} \mathrm{C}$. The authors found that the set of indicators of finished products for the production of sour-milk drinks with a complex of apiproducts, it is necessary to choose a three-strain poly fermentation product with a congruent ratio of cultures and set optimal fermentation regimes $39 \pm 1^{\circ} \mathrm{C}$ for $5.0 \pm 0.3$ hours.
\end{abstract}

Keywords: apiproduct; sour-milk drink; fermentation temperature; technological systems

\section{INTRODUCTION}

It is known that in the development of fermented dairy products, the components that are part of raw milk, changes in their composition, and properties in the connection are considered as a technological system (Parmjit, 2011; Palamarchuk et al., 2019). Its elements are independent and conditionally indivisible units that interact with each other and with the external environment (Balduzzi and Tononi, 2008; Kozelová et al., 2011). The set of elements and their connections form the structure of the system, and its spatio-temporal fragments - functional subsystems (Mda et al., 2019; Kim et al., 2015). The structure of the technological system for the manufacture of a sour-milk drink from apiproduct (Grujić et al., 2011) is presented in Table 1. The elements of the subsystems can function together and sequentially, in accordance with the tasks (Giachetti, 2006; Rogovskii et al., 2019b). The main element of subsystem A is natural cow's milk, which provides the nutritional and biological value of the developed product (Górska-Warsewicz et al., 2019). The nutritional value of milk is determined by its chemical composition, which is well studied and available in the literature (Barłowska et al., 2011), is relatively stable and does not require additional research (Rogovskii et al., 2019a). Milk is a structural unit of the technological system "raw milk-apiproduct-starter cultures", which is the environment of bioagents of fermentation - representatives of subsystem B (Vieites et al., 2008). The result of this process is the biotransformation of components of subsystems A and B, which ensures the quality and properties of the future product (Nikolic, 2018). The elements of subsystem B are lyophilized lactic acid microorganisms with known characteristics (Table 2) and therefore it did not require in-depth study (Azat et al., 2016). In contrast to the components of subsystem $B$ (apiproducts), which required careful examination, their characteristics may change over time (Bishop et al., 2012) and botanical origin (Bober et al., 2020).

\section{Scientific hypothesis}

The scientific hypothesis assumes the existence of functional dependence in the fermentation process of three types of associations of lactic acid bacteria in the technological system with a complex of apiproducts and without them. The fermented milk process should be more active in the experimental media, as the hydrogen index should be lower than in the control ones. 
Table 1 The structure of the technological system of sour-milk drink with apiproducts.

\begin{tabular}{ccc}
\hline Subsystem & Elements of subsystems & $\begin{array}{c}\text { Subsystem } \\
\text { components }\end{array}$ \\
\hline A & $\begin{array}{c}\text { The components, that regulate the nutritional, biological and energy value of sour } \\
\text { milk drink, are the living environment of biological objects }\end{array}$ & Raw milk \\
B & Components (growth factors) that regulate the activity and viability of biological & Apjects \\
C & Bioobjects that regulate fermentation & Starter cultures \\
\hline
\end{tabular}

Table 2 Characteristics of lactic acid bacteria.

\begin{tabular}{ccccc}
\hline Lactic acid bacteria & $\begin{array}{c}\text { Temperature } \\
\text { optimum, }{ }^{\mathbf{0}} \mathbf{C}\end{array}$ & $\begin{array}{c}\text { Interfacial } \\
\text { acidity, }{ }^{\mathbf{0}} \mathbf{T}\end{array}$ & $\begin{array}{c}\text { Coagulation } \\
\text { time, hour }\end{array}$ & $\begin{array}{c}\text { Temperature } \\
\text { range, }{ }^{\mathbf{0}} \mathbf{C}\end{array}$ \\
\hline Lactococcus lactis & $25-30$ & $125^{*}$ & $4-6$ & $10-40$ \\
S. thermophilus & $40-45$ & $110-115$ & $3.5-4$ & $20-50$ \\
L. acidophilus & $37-38$ & $260-280$ & $5-8$ & $5-53$ \\
L. bulgaricus & $40-45$ & $200-350$ & $4-6$ & $20-50$ \\
B. longum & $36-40$ & $120-130$ & $10-12$ & $20-50$ \\
\hline
\end{tabular}

Note: $*$-achieved in $5-7$ days.

\section{MATERIAL AND METHODOLOGY}

Given that food technology, based on the use of the pure culture of one microorganism, is limited by the possibilities of its enzyme systems, the ultimate goal may not be achieved even by changing the conditions and parameters of cultivation for ISO 27205:2010 (ISO 27205:2010). Biological systems with a wider internal variety of signs, properties, and qualities have higher viability. For the success of fermentation processes in the technological system, it is promising to use a combination of cultures, associations of microorganisms with a wide range of enzymes in contrast to one culture.

The next series of experiments were conducted for a comparative study of technological processes in normalized milk (control technological system) and the milk environment with the complex of apiproduct (experimental technological system) with the participation of poly ferments of different bacterial composition.

First of all, two variants of associations were studied: the first consisted of three cultures - S. thermophilus, L. acidophilus, L. bulgaricus. The second, in addition to these, additionally contained a fourth species of microorganisms - Lactococcus lactis (Table 3).

Table 3 Scheme of the presence of cultures in associations.

\begin{tabular}{ccccc}
\hline $\begin{array}{c}\text { Component of the } \\
\text { technological } \\
\text { system }\end{array}$ & \multicolumn{5}{c}{ Samples } \\
\cline { 2 - 5 } & K1 & K2 & D1 & D2 \\
\hline $\begin{array}{c}\text { Prepared cow's } \\
\text { milk }\end{array}$ & + & + & + & + \\
Complex of & - & - & + & + \\
apiproducts & & & & \\
S. thermophilus & + & + & + & + \\
L. acidophilum & + & + & + & + \\
L. bulgaricus & + & + & + & + \\
Lactococcus lactis & + & - & + & - \\
\hline
\end{tabular}

\section{Statistic analysis}

Statistical analysis of the results of experimental studies was performed in five replicates using standard methods of research of organoleptic, physical, physicochemical, microbiological, and other indicators. The obtained results of experimental research are processed using modern analytical integrated systems Microsoft Excel 2016 and Statistica 13.3. Adequacy of decision-making was carried out according to the criteria of Fisher, Cochran, and Student.

\section{RESULTS AND DISCUSSION}

Four samples took part in the experiment: two control samples $-\mathrm{K} 1$ and $\mathrm{K} 2$, which did not contain apiproduct and two experimental samples - D1 and D2, obtained by fermentation of the technological system "raw milkapiproduct-starter cultures". Similar studies were conducted by the authors of the following scientific papers (Banik et al., 2003; Abdul Manan and Webb, 2017; Montemurro et al., 2019). The ratio of cultures in fermentation products was congruent within each, incubation was performed at a temperature of $39-40^{\circ} \mathrm{C}$. In scientific works (Ospina, Merrill and Benson, 2018; Smith et al., 2018) incubation was performed at a temperature of $28-34{ }^{\circ} \mathrm{C}$. Titrated and active acidity was determined within 6 to 12 hours every 60 minutes. In scientific works (Shanina et al., 2019; Wijnen et al., 2020) titrated and active acidity were determined for seven hours with an interval of 30 to 120 minutes. Samples D1 and D2 were compared with control ones (Figure 1).

Studies of acid-forming activity in control and experimental environments have shown that apiproduct has a positive effect on the fermentation process, accelerating it (Todorov et al., 2017). In particular, cultures grown in experimental technological systems with apiproduct overcame the stage of preparation of microorganisms for reproduction (lag phase) 2 times faster. This was more noticeable in the example of sample K2 (Furtado et al., 2014). This may be due to the lower acid-forming capacity 


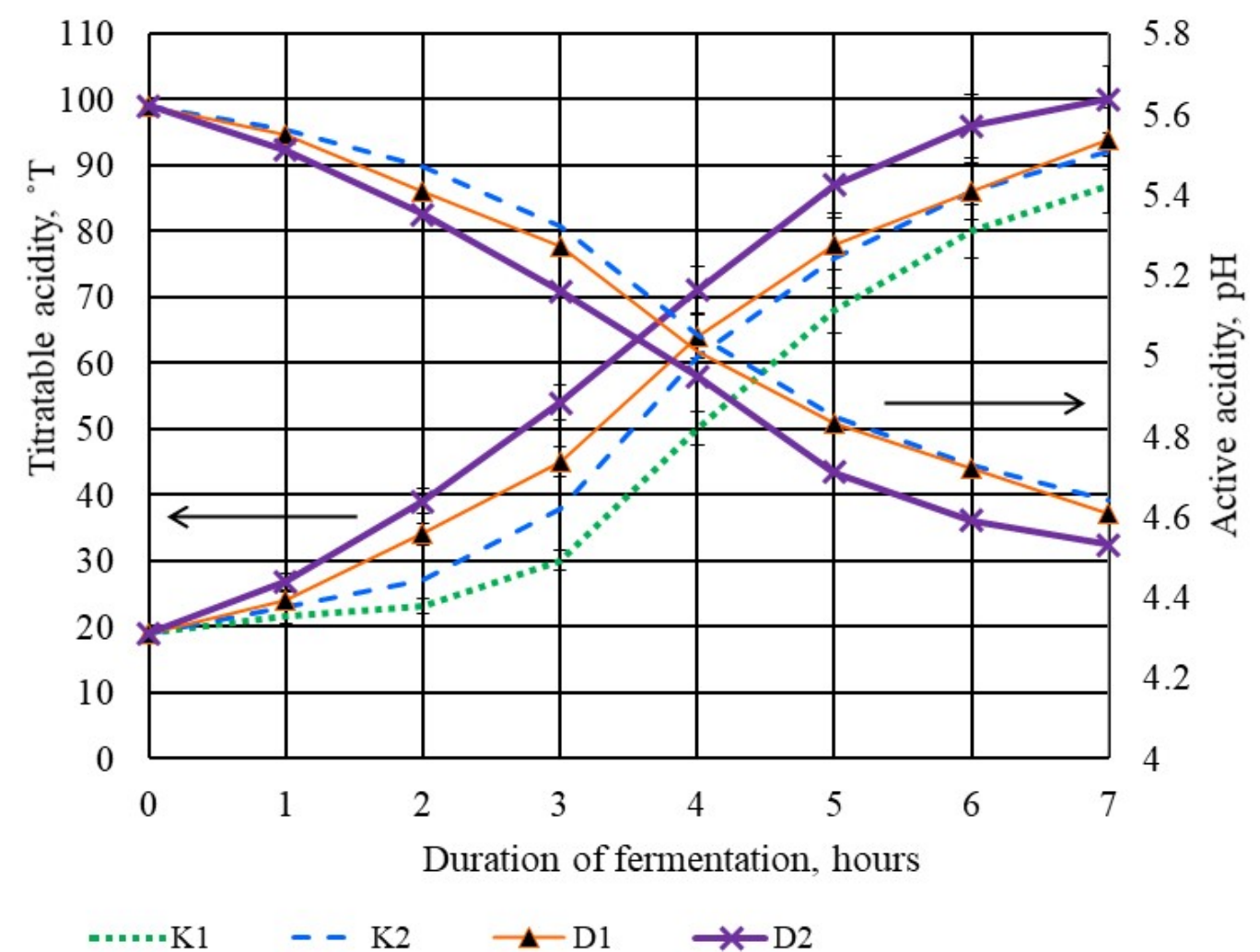

Figure 1 Dynamics of acidity of technological systems.

Table 4 Organoleptic parameters of sour-milk clots under the action of various associations of microorganisms.

\begin{tabular}{ccc}
\hline \multirow{2}{*}{ Sample } & \multicolumn{2}{c}{ Organoleptic parameters } \\
\cline { 2 - 3 } & consistency and color & taste and smell \\
K1 & Moderately dense, slightly brittle and viscous & Pure, sour-milk, fresh taste \\
K3 & Viscous, dense, homogeneous & Sour milk, moderately sour \\
K4 & Homogeneous, viscous & Taste and smell are satisfactory \\
D1 & The texture is viscous, slightly heterogeneous & Taste and smell are satisfactory \\
& The yellow clot is homogeneous, moderately dense & Sweet, not sour enough with a pleasant taste \\
D2 & The clot of pleasant yellow color, homogeneous, & Harmonious sweet and sour, with a pleasant \\
D3 & dense, viscous & taste and smell of apiproducts \\
D4 & Viscous sour milk gel with a yellow tint & Taste and smell are satisfactory \\
\end{tabular}

of Lactococcus lactis compared to L. acidophilus and L. bulgaricus. The reduction of the lag phase is a positive phenomenon, as it will reduce the likelihood of the development of unwanted microflora in the initial stages of fermentation of the technological system (Sahu and Panda, 2018), when the acidity has not risen to a safe level yet (Adebo et al., 2017).

The phase of smooth growth of biomass (log-phase) was also more productive in the technological system with the apiproduct complex for both starter cultures complex, but the association, which contained Lactococcus lactis, lagged behind the speed and efficiency of fermentation at all stages of microflora development (Singh et al., 2015). So, the starter cultures complex, which includes $S$. thermophilus, L. acidophilus, L. bulgaricus, proved to be better in both control and experimental environments (Glušac et al., 2015). To justify the choice of one of the two options for combinations of poly fermentation products (Dafeo and Daugulis, 2013), an additional organoleptic evaluation was performed (Table 4) and the ability of the sour-milk drink to emit the moisture (syneresis) was compared.

It was found that the use of different ferments in the presence of apiproduct in milk provides products with different flavors (Widyastuti et al., 2014). Thus, sour-milk drinks obtained by fermentation of the technological system "raw milk-apiproduct-starter cultures" had an appetizing appearance, pleasant color, pure sour-milk-honey smell, but the taste was not harmonious enough due to insufficient acidity. Sample D2, obtained by using three cultures (S. thermophilus, L. acidophilus, L. bulgaricus) had an appetizing appearance, pleasant sour-milk-honey aroma, and harmonious taste (Spence et al., 2017).

The synergistic properties of sour-milk gels obtained by fermentation of the technological system "raw milkapiproduct-starter cultures" indicate in favor of a threestrain combination of microorganisms, as sour-milk drinks, obtained by its use, better retain moisture in their structure (Figure 2). 


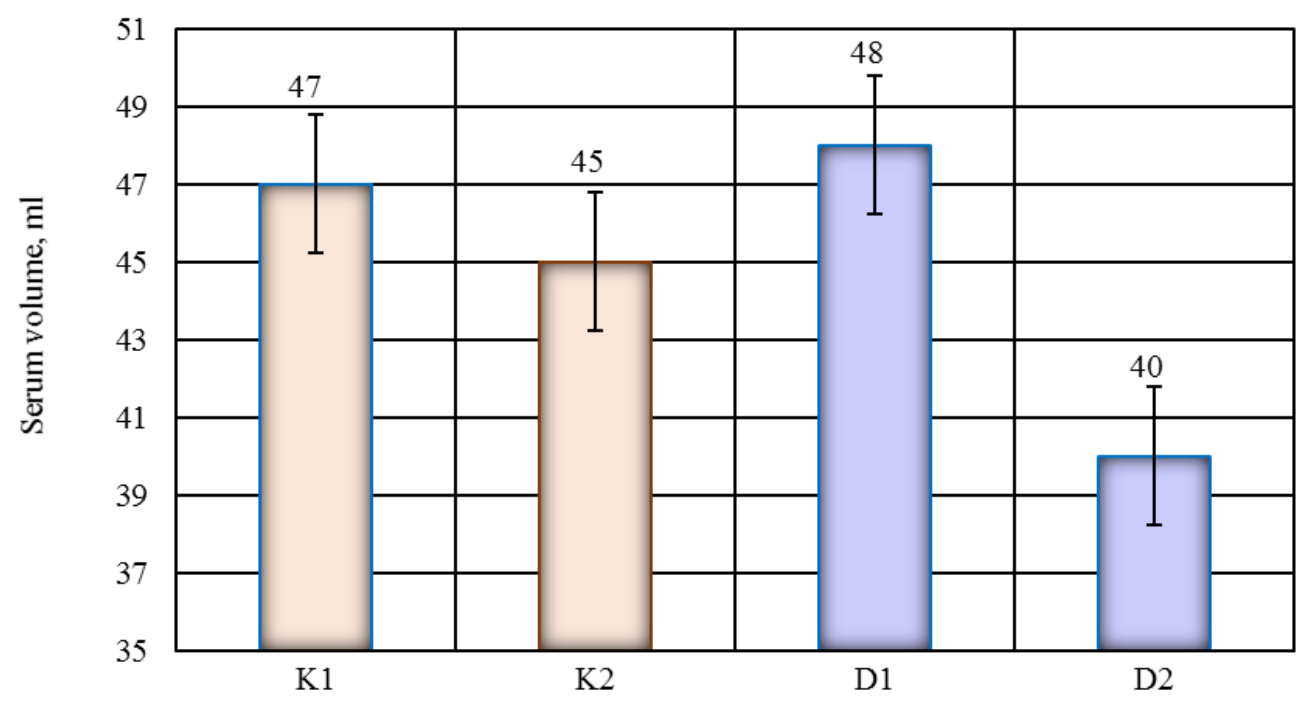

Figure 2 Synergetic properties of fermented technological systems.

Table 5 The structure of technological systems for studying the properties of associations of microorganisms.

\begin{tabular}{|c|c|c|c|c|c|c|c|c|}
\hline \multirow{3}{*}{ Component of the technological system } & \multicolumn{8}{|c|}{ Samples } \\
\hline & \multicolumn{4}{|c|}{ control } & \multicolumn{4}{|c|}{ experimental } \\
\hline & K1 & $\mathbf{K 2}$ & K3 & K4 & D1 & D2 & D3 & D4 \\
\hline Prepared cow's milk & + & + & + & + & + & + & + & + \\
\hline Complex of apiproducts & - & - & - & - & + & + & + & + \\
\hline 2/4 S. thermophilus, 1/4 L. acidophilus, 1/4 L. bulgaricus & + & - & - & - & + & - & - & - \\
\hline 1/3 S. thermophilus, 1/3 L. acidophilus, 1/3 L. bulgaricus & - & + & - & - & - & + & - & - \\
\hline 1/4 S. thermophilus, 1/4 L. acidophilus, 2/4 L. bulgaricus & - & - & + & - & - & - & + & - \\
\hline 1/4 S. thermophilus, 2/4 L. acidophilus, 1/4 L. bulgaricus & - & - & - & + & - & - & - & + \\
\hline
\end{tabular}

After 3 hours of filtration of the $100 \mathrm{ml}$ sample, less serum was released in $\mathrm{K} 1$ samples than in $\mathrm{D} 1$ by $1 \mathrm{ml}$ and in $\mathrm{K} 2$ more than in $\mathrm{D} 2$ by $5 \mathrm{ml}$. The difference between samples $\mathrm{K} 1$ and $\mathrm{K} 2$ was $2 \mathrm{ml}(4 \%)$, and between D1 and D2 - $8 \mathrm{ml}$ $(16.7 \%)$. Incubation of four-strain starter cultures complex in the medium with apiproducts led to a deterioration in the ability of the gel, formed by it, to retain moisture in the structure (Mushtruk et al., 2020).

This is evidenced by a $2 \%$ increase in the compression of the dispersion medium of sample D1 compared with K1. Thus, sour-milk gels formed by the starter cultures consisting of $S$. thermophilus, L. acidophilus, L. bulgaricus, retain moisture better than those formed by $S$. thermophilus, L. acidophilus, L. bulgaricus, Lactococcus lactis, the difference becomes more noticeable during the fermentation of the technological system "raw milkapiproduct-starter cultures". This may be due to the ability of the L. acidophilus, L. bulgaricus, Lactococcus lactis to form a sour-milk gel with a brittle structure that displaces the dispersion medium. In contrast to lactic acid mucusforming rods (L.acidophilus, L. bulgaricus) and thermophilic streptococcus, which form clots of viscous and creamy consistency (Sfakianakis and Tzia, 2014), which provides low self-expression of serum.

A comparative evaluation of the action of two starter cultures by the set of signs of leaven, in dairy environments with a complex of apiproduct and without it, suggests that in further studies we should use the first of them. Because the combination of S. thermophilus, L. acidophilus, and L. bulgaricus provides the best quality in organoleptic, biochemical, technological, and others. properties of the product than poly fermentation product with the composition: S. thermophilus, L. acidophilus, L. bulgaricus, Lactococcus lactis.

Substantiation of fermentation regimes and composition of poly cultural leaven (Kennedy and Krouse, 1999). The biochemical activity of microorganisms should be studied under the conditions of a set of influencing factors: the composition of the nutrient medium, the temperature of cultivation, the composition of the leaven (Beltran et al., 2008; Bober et al., 2020). The influence of the first factor was investigated using two variants of media: the first normalized milk with a mass fraction of fat of $3.2 \%$, pasteurized at a temperature of $87 \pm 2{ }^{\circ} \mathrm{C}$, and cooled to fermentation temperature, the second - the same milk with a complex additive. The effect of the second factor was investigated by varying the cultivation temperature (Table 2) from $38^{\circ} \mathrm{C}$ to $42^{\circ} \mathrm{C}$ in increments of $2^{\circ} \mathrm{C}$. Temperatures above $42{ }^{\circ} \mathrm{C}$ are undesirable for the apiproduct. The influence of the third factor was studied by changing the ratio of cultures in the starter cultures. As a result of the technological system of design, eight samples of sour-milk clots were obtained (Table 5): control - K1-K4 and experimental - D1-D4.

As a result of designing the technological system, eight samples of sour-milk clots were obtained, which differed in the presence of apiproduct in their composition and were fermented by different. Lactic acid bacteria (LAB) associations (Fahrurrozi et al., 2019). Control and experimental samples were evaluated by coagulation time 
and titrated acidity (Marchi et al., 2009; Zheplinska et al., 2020). The research results are presented in Table 6.

Analyzing the biochemical activity of the association of lactic acid cultures in control and experimental of the technological system at a cultivation temperature of $38-42{ }^{\circ} \mathrm{C}$, we can conclude that, under these conditions, environments with apiproduct complex performed better than control ones.

The results of the study of culture activity under different cultivation conditions showed that an increase in biomass was obtained in environments with apiproducts, which is higher than in the control ones by $7.4 \%$. In scientific works (Barãoa et al., 2019; Abdulgader et al., 2019) descriptive experiments where the increase in biomass obtained in environments with a variety of products ranged only at the level of $3.5-4.6 \%$.

Increasing the fermentation temperature by $2{ }^{\circ} \mathrm{C}$ causes an increase in acidity by $1^{\circ} \mathrm{T}$, a similar effect on the content of Log CFU ml-1 is not observed.
The number of lactic acid bacteria grown at a temperature of $3{ }^{\circ} \mathrm{C}$ was higher than the number grown at a temperature of $40{ }^{\circ} \mathrm{C}$ by $1.0 \%$ in the control group and $2.0 \%$ in the experimental group.

A further increase in the fermentation temperature to $42{ }^{\circ} \mathrm{C}$ caused an inverse reaction, which resulted in a decrease in the number of viable cells, both in the control and in the experiment, by an average of $3.4 \%$, compared with samples cultured at $40{ }^{\circ} \mathrm{C}$ by $2 \%$ compared to those samples that were fermented at a temperature of $38^{\circ} \mathrm{C}$.

As the fermentation temperature increases, the acidity of the clots increases - protein coagulation is faster by almost one hour, but under such conditions, there is a tendency to reduce the synthesis of biomass.

The time of clot formation has a directly proportional effect on the duration of the production process, and acid coagulation of milk correlates with the level of organic acids in the environment.

However, with the acceleration of coagulation, as can be seen from Table 6, the ability of microorganisms to

Table 6 Activity of cultures under different conditions of cultivation, $n=3, p \leq 0.05$

\begin{tabular}{|c|c|c|c|}
\hline Sample & Titrated acidity, ${ }^{\circ} \mathbf{T}$ & Time of Gel formation, hour & $\begin{array}{c}\text { Cell numbers } \\
\log \mathrm{LAB} / \mathrm{g}\end{array}$ \\
\hline \multicolumn{4}{|c|}{ Cultivation temperature $38^{\circ} \mathrm{C}$} \\
\hline K1 & $85 \pm 1$ & $5.5 \pm 0.3$ & $8.7 \pm 0.2$ \\
\hline D1 & $90 \pm 3$ & $5.0 \pm 0.1$ & $9.4 \pm 0.1$ \\
\hline $\mathbf{K} 2$ & $84 \pm 2$ & $5.6 \pm 0.2$ & $8.8 \pm 0.1$ \\
\hline D2 & $89 \pm 3$ & $5.4 \pm 0.2$ & $9.3 \pm 0.2$ \\
\hline K3 & $88 \pm 1$ & $5.3 \pm 0.5$ & $8.5 \pm 0.2$ \\
\hline D3 & $92 \pm 1$ & $4.8 \pm 0.3$ & $9.3 \pm 0.1$ \\
\hline K4 & $87 \pm 2$ & $5.4 \pm 0.3$ & $8.6 \pm 0.1$ \\
\hline D4 & $91 \pm 3$ & $4.9 \pm 0.1$ & $9.3 \pm 0.1$ \\
\hline \multicolumn{4}{|c|}{ Cultivation temperature $40{ }^{\circ} \mathrm{C}$} \\
\hline K1 & $86 \pm 1$ & $5.4 \pm 0.1$ & $8.8 \pm 0.1$ \\
\hline D1 & $91 \pm 1$ & $4.7 \pm 0.1$ & $9.5 \pm 0.2$ \\
\hline $\mathbf{K} 2$ & $85 \pm 1$ & $5.5 \pm 0.2$ & $8.9 \pm 0.3$ \\
\hline D2 & $89 \pm 2$ & $4.9 \pm 0.1$ & $9.3 \pm 0.3$ \\
\hline K3 & $89 \pm 2$ & $5.2 \pm 0.1$ & $8.7 \pm 0.2$ \\
\hline D3 & $94 \pm 2$ & $4.5 \pm 0.2$ & $9.3 \pm 0.2$ \\
\hline K4 & $88 \pm 3$ & $5.3 \pm 0.3$ & $8.5 \pm 0.3$ \\
\hline D4 & $92 \pm 1$ & $4.6 \pm 0.2$ & $9.3 \pm 0.1$ \\
\hline \multicolumn{4}{|c|}{ Cultivation temperature $42{ }^{\circ} \mathrm{C}$} \\
\hline K1 & $88 \pm 1$ & $4.8 \pm 0.1$ & $8.5 \pm 0.1$ \\
\hline D1 & $93 \pm 2$ & $4.0 \pm 0.1$ & $9.3 \pm 0.3$ \\
\hline $\mathbf{K} 2$ & $86 \pm 2$ & $4.9 \pm 0.2$ & $8.5 \pm 0.2$ \\
\hline D2 & $90 \pm 1$ & $4.2 \pm 0.2$ & $9.2 \pm 0.1$ \\
\hline K3 & $90 \pm 2$ & $4.6 \pm 0.2$ & $8.4 \pm 0.1$ \\
\hline
\end{tabular}

Table 7 Characteristics of products obtained under different fermentation regimes.

\begin{tabular}{cccccccccc}
\hline & \multicolumn{7}{c}{ Fermentation temperature } \\
\cline { 2 - 10 } Sample & \multicolumn{7}{c}{$\mathbf{3 8}^{\mathbf{0}} \mathbf{C}$} & $\mathbf{4 0}{ }^{\mathbf{0}} \mathbf{C}$ & \multicolumn{3}{c}{$\mathbf{4 2}^{\mathbf{}} \mathbf{C}$} \\
\cline { 2 - 10 } & score & viscosity, sec. & $\mathbf{p H}$ & score & viscosity, sec. & $\mathbf{p H}$ & score & viscosity, sec. & $\mathbf{p H}$ \\
\hline K1 & 5 & $83 \pm 1$ & $4.7 \pm 0.03$ & 4.9 & $83 \pm 2$ & $4.7 \pm 0.02$ & 4.9 & $84 \pm 1$ & $4.6 \pm 0.09$ \\
D1 & 5 & $84 \pm 1$ & $4.6 \pm 0.07$ & 5.0 & $84 \pm 2$ & $4.6 \pm 0.05$ & 4.9 & $84 \pm 3$ & $4.6 \pm 0.03$ \\
K2 & 4.9 & $70 \pm 2$ & $4.7 \pm 0.05$ & 4.9 & $71 \pm 3$ & $4.7 \pm 0.03$ & 4.8 & $73 \pm 2$ & $4.7 \pm 0.02$ \\
D2 & 4.9 & $79 \pm 1$ & $4.6 \pm 0.08$ & 4.9 & $80 \pm 3$ & $4.6 \pm 0.07$ & 4.8 & $80 \pm 2$ & $4.6 \pm 0.07$ \\
K3 & 4.4 & $80 \pm 2$ & $4.6 \pm 0.09$ & 4.4 & $81 \pm 1$ & $4.6 \pm 0.08$ & 4.3 & $80 \pm 3$ & $4.6 \pm 0.07$ \\
D3 & 4.7 & $83 \pm 1$ & $4.6 \pm 0.04$ & 4.7 & $83 \pm 3$ & $4.6 \pm 0.03$ & 4.6 & $83 \pm 1$ & $4.6 \pm 0.01$ \\
K4 & 4.5 & $80 \pm 1$ & $4.7 \pm 0.01$ & 4.5 & $80 \pm 2$ & $4.6 \pm 0.09$ & 4.4 & $81 \pm 1$ & $4.6 \pm 0.08$ \\
D4 & 4.8 & $82 \pm 2$ & $4.6 \pm 0.05$ & 4.7 & $82 \pm 2$ & $4.6 \pm 0.04$ & 4.6 & $82 \pm 1$ & $4.6 \pm 0.01$ \\
\hline
\end{tabular}


accumulate biomass decreases, and the number of viable cells decreases, both in control and in the experiment.

For example, in the control of acidity $85{ }^{\circ} \mathrm{T}$ Log CFU ml-1 is 8.7 , and at an acidity of $88^{\circ} \mathrm{T}-8.5$, and the time of clot formation at the specified acidity is reduced by $13 \%$. Similar dynamics are observed in the experimental samples, but the loss of cell concentration for every $1^{\circ} \mathrm{T}$ is twice lower. It should be noted that coagulation should not be accelerated while neglecting the probiotic properties of the sour-milk drink. Therefore, the recommended fermentation regimes are $39 \pm 1{ }^{\circ} \mathrm{C}$ for $5.0 \pm 0.3$ hours of fermentation. Analyzing the results of the model associations of microorganisms, we can conclude that the best results were achieved by those who had a congruent ratio of cultures (K1, D1), both in environments with apiproduct and without them.

Studies of organoleptic, physicochemical, and rheological properties of cultures of lactic acid organisms under different cultivation conditions are presented in Table 7.

The data obtained indicate that with increasing fermentation temperature, there is a tendency to accelerate the decrease in the concentration of hydrogen ions and a slight increase in viscosity. A more pronounced difference was observed in the number of points scored between control and experimental samples, fermented under different conditions (Woo et al., 2019). An increase in the cultivation temperature by $2{ }^{\circ} \mathrm{C}$ causes such negative phenomena as excessively sour taste, intense serum secretion, minor defects in the consistency of the sour-milk clot (flakes, etc.) and it leads to a decrease in the overall score by an average of 0.4 points for all samples.

Thus, the results of the research of organoleptic, physicochemical, and rheological properties of LAB cultures under different cultivation conditions indicate that fermentation should be carried out at a temperature of $38-40^{\circ} \mathrm{C}$.

\section{CONCLUSION}

During the study of the fermentation process of three species associations of lactic acid bacteria in technological systems with a complex of apiproducts and without them, it was noted that the sour-milk process is more active in the experimental environment because the hydrogen index was lower than in control ones.

Sensory evaluation of sour-milk drinks showed that the best taste properties had experimental samples. This is because the sweet taste of honey was harmoniously combined with sour-milk, and the floral aroma of the apiproduct successfully emphasized the characteristic smell of fermented dairy products. The highest score among the experimental samples scored D1 and D2, but the relative viscosity of the sample D1 was higher by $6 \%$ and was $83-85$ seconds.

All experimental samples (D1 - D4) in the set of indicators prevailed control ones $(\mathrm{K} 1-\mathrm{K} 4)$, but the leader was the sample D2, fermented with an equal ratio of cultures at a temperature of $38-40{ }^{\circ} \mathrm{C}$.

Therefore, according to the results of the study of the set of indicators of finished products for the production of sourmilk beverages with a complex of apiproducts, a three-strain poly fermentation product with a congruent ratio of cultures was selected and optimal fermentation regimes were established: $39 \pm 1{ }^{\circ} \mathrm{C}$ for $5.0 \pm 0.3$ hours.

\section{REFERENCES}

Abdul Manan, M., Webb, C. 2017. Modern microbial solid state fermentation technology for future biorefineries for the production of added-value products. Biofuel Research $\begin{array}{lllll}\text { Journal, vol. } 4, \quad \text { no. } 4, & \text { p. } & 730-740 .\end{array}$ https://doi.org/10.18331/BRJ2017.4.4.5

Abdulgader, M., Yu, J., Zinatizadeh, A. A., Williams, P., \& Rahimi, Z. 2019. Process analysis and optimization of single stage flexible fibre biofilm reactor treating milk processing industrial wastewater using response surface methodology (RSM). Chemical Engineering Research and Design, vol. 149, p. 169-181. https://doi.org/10.1016/j.cherd.2019.07.011

Adebo, O. A., Njobeh, P. B., Mulaba-Bafubiandi, A. F., Adebiyi, J. A., $\quad$ Desobgo, Z. S., $\quad$ Kayitesi, E. 2017. Optimization of fermentation conditions for ting production using response surface methodology. Journal of Food Process Preserve, vol. 42, no. 1, p. e13381. https://doi.org/10.1111/jfpp.13381

Azat, R., Liu, Y., Li, W., Kayir, A., Lin, D., Zhou, W., Zheng, X. 2016. Probiotic properties of lactic acid bacteria isolated from traditionally fermented Xinjiang cheese. Journal of Zhejiang Univercity Science B, vol. 17, no. 8, p. 597-609. https://doi.org/10.1631/jzus.B1500250

Balduzzi, D., Tononi, G. 2008. Integrated information in discrete dynamical systems: motivation and theoretical framework. PLoS Computational Biology, vol. 4, issue 6, p. e1000091. https://doi.org/10.1371/journal.pcbi.1000091

Banik, R., Santhiagu, A., Kanari, B., Sabarinath, C., Upadhyay, S. 2003. Technological aspects of extractive fermentation using aqueous two-phase systems. World Journal of Microbiology and Biotechnology, vol. 19, no. 4, p. 337-348. https://doi.org/10.1023/A:1023940809095

Barãoa, C., Klososkia, S., Pinheiroa, K., Marcolinoa, V., Juniorb, O., da Cruzc, A., Pimentela, T. 2019. Growth kinetics of kefir biomass: Influence of the incubation temperature in milk. Chemical engineering, vol. 75, p. 499-504.

Barłowska, J., Szwajkowska, M., Litwińczuk, Z., Król, J. 2011. Nutritional value and technological suitability of milk from various animal species used for dairy production. Comprehensive Reviews in Food Science and Food Safety, vol. 10, no. 6, p. 291-302. https://doi.org/10.1111/j.15414337.2011.00163.x

Beltran, G., Novo, M., Guillamon, J., Nicolas Rozès, N. 2008. Effect of fermentation temperature and culture media on the yeast lipid composition and wine volatile compounds. International Journal of Food Microbiology, vol. 121, p. 169177. https://doi.org/10.1016/j.ijfoodmicro. 2007.11.030

Bishop, M., James, A., Shroder, J., Walsh, S. 2012. Geospatial technologies and digital geomorphological mapping: concepts, issues and research. Geomorphology, vol. 137, no. 1 , p. 5-26. https://doi.org/10.1016/j.geomorph. $\underline{2011.06 .027}$

Bober, A., Liashenko, M., Protsenko, L., Slobodyanyuk, N., Matseiko, L., Yashchuk, N., Gunko, S., Mushtruk, M. 2020. Biochemical composition of the hops and quality of the finished beer. Potravinarstvo Slovak Journal of Food Sciences, vol. 14, no. 1, p. 307-317. https://doi.org/10.5219/1311

Bober, A., Liashenko, M., Protsenko, L., Slobodyanyuk, N., Matseiko, L., Yashchuk, N., Gunko, S.,Mushtruk, M. 2020). Biochemical composition of the hops and quality of the finished beer. Potravinarstvo Slovak Journal of Food Sciences, vol. 14, p. 307-317. https://doi.org/10.5219/1311

Dafeo, J., Daugulis, A. 2013. In situ product removal in fermentation systems: Improved process performance and rational extractant selection. Biotechnology Letters, vol. 36, no. 3, p. 37-46. https://doi.org/10.1007/s10529-013-1380-6 
Fahrurrozi, F., Rahayu, E. K., Imam B. Nugroho, I. M., Lisdiyanti P. 2019. Lactic acid bacteria (LAB) isolated from fermented cocoa beans prevent the growth of model foodcontaminating bacteria. AIP Conference Proceedings, vol. 2099, issue 1, p. 020005. https://doi.org/10.1063/1. $\underline{5098410}$

Furtado, D. N., Todorov, S. D., Landgraf, M., Destro, M. T., Franco, B. D. 2014. Bacteriocinogenic Lactococcus lactis subsp. Lactis DF04Mi isolated from goat milk: characterization of the bacteriocin. Brazilian Journal of Microbiology, vol. 45, no. 4, p. 24-37. http://doi.org/ 10.1590/ S1517$\underline{83822014000400052}$

Giachetti, R. E. 2006. Understanding interdependence in enterprise systems: a model and measurement formalism. Proceedings of the 2006 International Conference on Business Process Management Workshops, vol. LNCS 4103, p. 257268. https://doi.org/10.1007/11837862 26

Glušac, J., Stijepić, M., Đurđević-Milošević, D., Milanović, S., Kanurić, K., Vukić, V., 2015. Growth and viability of Lactobacillus delbrueckii subsp. bulgaricus and Streptococcus thermophiles in traditional yoghurt enriched by honey and whey protein concentrate. Iranian Journal of Veterinary Research, vol. 16, no. 3, p. 249-254. https://doi.org/10.27175184/PMC4782693

Górska-Warsewicz, H., Rejman, K., Laskowski, W., Czeczotko, M. 2019. Milk and dairy products and their nutritional contribution to the average polish diet. Nutrients, vol. 11, no. 8, p. 287-298. https://doi.org/10.3390/nu 11081771

Grujić, R., Antonić, B., Vujadinović, D., Macanović, M. 2011. Traditional sour milk products as a basis for the development of new products in industrial conditions. Quality of Life. vol. 2, no. 3-4, p. 66-74. https://doi.org/10.7251/QOL1102066G

ISO 27205:2010. Quality management systems Requirements. International Standard Organisation.

Kennedy, M. J., Krouse, D. 1999. Strategies for improving fermentation medium performance: a review. Journal of Industrial Microbiology and Biotechnology, vol. 23, no. 6, p. 456-475. https://doi.org/10.1038/sj.jim.2900755

Kim, H., Angelaki, D., DeAngelis, G. 2015. A novel role for visual perspective cues in the neural computation of depth. Nature Neuroscience, vol. 18, no 1, p. 129-137. https://doi.org/10.1038/nn.3889

Kozelová, D. Mura, L., Matejková, E., Lopašovský, L., Vietoris, V., Mendelová, A., Bezáková, M., Chreneková, M. 2011. Organic products, consumer behavior on market and European organic product market situation. Potravinarstvo Slovak Journal of Food Sciences, vol. 5, no. 3, p. 20-26. https://doi.org/10.5219/96

Marchi, M. D., Fagan, C. C., O'Donnell, C. O., Bittante, G. 2009. Prediction of coagulation properties, titratable acidity, and $\mathrm{pH}$ of bovine milk using mid-infrared spectroscopy. Journal of Dairy Science, vol.92, no. 1, p. 423-432. https://doi.org/10.3168/jds.2008-1163

Mda, T. J., Khuman, A. S., Owa, K. 2019. Spatio-temporal patterns act as computational mechanisms governing emergent behavior in robotic swarms. International Journal of Swarm Intelligence and Evolutionary Computation, vol. 8, issue 1, p. 1-9. https://doi.org/10.4172/2090-4908.1000175

Montemurro, M., Pontonio, E., Gobbetti, M., Rizzello, C. G. 2019. Investigation of the nutritional, functional and technological effects of the sourdough fermentation of sprouted flours. International Journal of Food Microbiology, vol. $\quad 302, \quad$ p. $\quad 47-58$. https://doi.org/10.1016/j.ijfoodmicro.2018.08.005
Mushtruk, M., Vasyliv, V., Slobodaniuk, N., Mukoid, R., Deviatko, O. 2020. Improvement of the Production Technology of Liquid Biofuel from Technical Fats and Oils. In Ivanov, V., Trojanowska, J., Machado, J., Liaposhchenko, O., Zajac, J., Pavlenko, I., Edl, M., Perakovic, D. Advances in Design, Simulation and Manufacturing III. Switzerland : Springer International Publishing, p. 377-386. ISBN 21954364-21954356. https://doi.org/10.1007/978-3-03050491-5 36

Nikolic, J. 2018. Building "with the systems" vs. building "in the system" of ims open technology of prefabricated construction: challenges for new "infill" industry for massive housing retrofitting. Energies, vol. 11, p.11-28. https://doi.org/10.3390/en11051128

Ospina, E. A., Merrill, L., Benson, T. 2018. Incubation temperature impacts nestling growth and survival in an opencup nesting passerine. Ecology and evolution, vol. 8, no. 6, p. 3270-3279. https://doi.org/10.1002/ece3.3911

Palamarchuk, I., Mushtruk, M., Vasyliv, V., Zheplinska, M. 2019. Substantiation of regime parameters of vibrating conveyor infrared dryers. Potravinarstvo Slovak Journal of Food Sciences, vol. 13, no. 1, p. 751-758. https://doi.org/10.5219/1184

Parmjit, S. P. 2011. Fermented dairy products: starter cultures and potential nutritional benefits. Food and Nutrition Sciences, vol. 2, no. 1, p. 47-51. https://doi.org/10.4236/fns.2011.21006

Rogovskii, I. L., Titova, L. L., Trokhaniak, V. I., Rosamaha, Yu. O., Blesnyuk, O. V., Ohiienko, A. V. 2019a. Engineering management of two-phase coulter systems of seeding machines for implementing precision farming technologies. INMATEH. Agricultural Engineering, vol. 58, no. 2, p. 137-146. https://doi.org/10.35633/INMATEH-58-15

Rogovskii, I., Titova, L., Trokhaniak, V., Trokhaniak, O., Stepanenko, S. 2019b. Experimental study on the process of grain cleaning in a pneumatic microbiocature separator with apparatus camera. Bulletin of the Transilvania University of Brasov, Series II: Forestry, Wood Industry, Agricultural Food Engineering, vol. 12(61), no. 1, p. 117-128. https://doi.org/10.31926/but. fwiafe.2019.12.61.1.10

Sahu, L., Panda, S. K. 2018. Innovative technologies and implications in fermented food and beverage industries: an overview. Innovations in Technologies for Fermented Food and Beverage Industries, vol. April, p. 54-71. http://doi.org/10.1007/978-3-319-74820-7_1

Sfakianakis, P., Tzia, C. 2014. Conventional and innovative processing of milk for yogurt manufacture; development of texture and flavor: a review. Foods, vol. 3, no. 1, p. 176-193. https://doi.org/10.3390/foods3010176

Shanina, O., Galyasnyj, I., Gavrysh, T., Dugina, K., Sukhenko, Y., Sukhenko, V., Miedviedieva, N., Mushtruk, M., Rozbytska, T., Slobodyanyuk, N. 2019. Development of gluten-free non-yeasted dough structure as factor of bread quality formation. Potravinarstvo Slovak Journal of Food Sciences, vol. 13, p. 971-983. https://doi.org/10.5219/1201

Singh, M. S., Singh, K. N., Mandjiny, S., Holmes, L. 2015. Modeling the growth of Lactococcus lactis NCIM 2114 under differently aerated and agitated conditions in broth. Fermentation, vol. 1, p. 86-97. https://doi.org/10.3390/ fermentation 1010086

Smith, P., Finnegan, W., Ngo, T., Kronvall, G. 2018. Influence of incubation temperature and time on the precision of MIC and disc diffusion antimicrobial susceptibility test data. Aquaculture, vol. 490, p. 19-24. https://doi.org/10.1016/j.aquaculture.2018.02.020 
Spence, C., Wang, Q. J., Youssef, J. 2017. Pairing flavours and the temporal order of tasting. Flavour, vol. 6, no. 1, p. 112131. https://doi.org/10.1186/s13411-017-0053-0

Todorov, S., Stojanovski, S., Iliev, I., Moncheva, P., Nero, L., Ivanova, I. 2017. Technology and safety assessment for lactic acid bacteria isolated from traditional Bulgarian fermented meat product "lukanka". Brazilian Journal of Microbiology, vol. 48, no. 3, p. 5-18. https://doi.org/10.1016/j.bjm.2017.02.005

Vieites, J., Guazzaroni, M., Beloqui, A., Ferrer, M. 2008. Metagenomics approaches in systems microbiology. FEMS Microbiology Reviews, vol.33, no. 1, p. 236-255. https://doi.org/10.1111/j.1574-6976.2008.00152.x

Widyastuti, Y., Rohmatussolihat, R., Febrisiantosa, A., 2014. The role of lactic acid bacteria in milk fermentation. Food and Nutrition Sciences, vol. 05 , no. 04, p. 435-442. https://doi.org/10.4236/fns.2014.54051

Wijnen, H. J., Molenaar, R., van Roovert-Reijrink, I. A. M., van der Pol, C. W., Kemp, B., van den Brand, H. 2020. Effects of incubation temperature pattern on broiler performance. Poultry Science, vol. 99, no. 8, p. 3897-3907. https://doi.org/10.1016/j.psj.2020.05.010

Woo, S. M., Uyeh, D., Kim, J., Ha, Y. U. 2019. A study on the optimal fermentation conditions for mixed by-products in livestock feed production. Engineering in Agriculture, vol. 12, no. 4, p. 34-47. https://doi.org/10.1016/ j.eaef.2019.09.001

Zheplinska, M., Mushtruk, M., Kos, T., Vasyliv, V., Kryzhova, Y., Mukoid, R., Bilko, M., Kuts, A., Kambulova, Y., Gunko, S. 2020. The influence of cavitation effects on the purification processes of beet sugar production juices. Potravinarstvo Slovak Journal of Food Sciences, vol. 14, p. 451-457. https://doi.org/10.5219/1284

\section{Contact address:}

Ivan Rogoskii, National University of Life and Environmental Sciences of Ukraine, Research Institute of Engineering and Technology, Heroes of Defense Str., 15, Kyiv, 03041, Ukraine, Tel.: +38(098)440-52-83,

E-mail: rogovskii@,nubip.edu.ua

ORCID: https://orcid.org/0000-0002-6957-1616

*Mikhailo Mushtruk, National University of Life and Environmental Sciences of Ukraine, Faculty of Food Technology and Quality Control of Agricultural Products, Department of Processes and Equipment for Processing of Agricultural Production, Heroes of Defense Str., 12 B, Kyiv, 03040, Ukraine, Tel.: +38(098)941-26-06,

E-mail: mixej.1984@ukr.net

ORCID: https://orcid.org/0000-0002-3646-1226

Liudmyla Titova, National University of Life and Environmental Sciences of Ukraine, Research Institute of Engineering and Technology, Heroes of Defense Str., 15, Kyiv, 03041, Ukraine, Tel.: +38(097)834-90-22,

E-mail: L titova@nubip.edu.ua

ORCID: $\underline{\text { https://orcid.org/ 0000-0001-7313-1253 }}$
Olha Snezhko, National University of Life and Environmental Sciences of Ukraine, Faculty of Food Technology and Quality Control of Agricultural Products, Department Technologies of Meat, Fish and Marine Products, Heroes of Defense Str., 15, Kyiv, 03041, Ukraine, Tel.: +38(099)065-10-54,

E-mail: snezhkoolha@gmail.com

ORCID: https://orcid.org/0000-0002-1405-884X

Svitlana Rogach, National University of Life and Environmental Sciences of Ukraine, Faculty of Food Technology and Quality Control of Agricultural Products, Department Enterprise Economics named after Prof. I. N. Romanenko, Heroes of Defense Str, 15, Kyiv, 03041, Ukraine, Tel.: +38(067)299-96-19,

E-mail: rogach_sm@ukr.net

ORCID: https://orcid.org/0000-0001-6940-1935

Oleh Blesnyuk, Kharkiv National Technical University of Agriculture named after Petro Vasylenko, Educational and Scientific Institute of Technical Service, Heroes of Defense Str., 15, Kyiv, 03041, Ukraine, Tel.: +38(050)500-44-45,

E-mail: bleznyuk@ukr.net

ORCID: https://orcid.org/0000-0002-7928-117X

Yuriy Rosamaha, National University of Life and Environmental Sciences of Ukraine, Research Institute of Engineering and Technology, Heroes of Defense Str., 15, Kyiv, 03041, Ukraine, Tel.: +38(096)0251-87-09,

E-mail: rosamaha.vchenyij@,ukr.net

ORCID: https://orcid.org/0000-0001-9818-0246

Tetiana Zubok, National University of Life and Environmental Sciences of Ukraine, Research Institute of Engineering and Technology, Heroes of Defense Str., 15, Kyiv, 03041, Ukraine, Tel.: +38(097)578-15-99,

E-mail: tanyzubok@gmail.com

ORCID: https://orcid.org/ 0000-0001-7559-0859

Oleksandr Yeremenko, National University of Life and Environmental Sciences of Ukraine, Research Institute of Engineering and Technology, Heroes of Defense Str., 15, Kyiv, 03041, Ukraine, Tel.: +38(097)355-41-65,

E-mail: eremolex@ukr.net

ORCID: https://orcid.org/ 0000-0002-3377-0015

Oleksandr Nadtochiy, National University of Life and Environmental Sciences of Ukraine, Research Institute of Engineering and Technology, Heroes of Defense Str., 15, Kyiv, 03041, Ukraine, Tel.: +38(067)244-21-23, E-mail: o.nad@ukr.net ORCID: https://orcid.org/ 0000-0002-2876-3021

Corresponding author: * 